bearing walls enables the space to be utilized in a very economical way.

The larger lecture theatre contains seating for 180 and the smaller for 105. Each has bench-type seating, specially modelled for maximum comfort, and fitted with hinged writing flaps. In each theatre the lecturer's demonstration bench is equipped with all laboratory services and, in addition, the electrically operated windows, blinds and dimming apparatus for the lighting can be controlled from it. The walls behind the demonstration benches are prepared to form a permanent projection surface $12 \mathrm{ft}$. wide and $6 \mathrm{ft}$. high, on which two pictures can be projected side by side. Below the projection surface is a 12-ft. glass chalk-board. On the left-hand side of the central wall is a splayed wall with a translucent glass chalk-board, which can be illuminated from behind when the room is darkened; on the right-hand side is another splayed wall fitted with a chalk-board of conventional type.

Heating in the lecture theatres is by means of radiant wall panels combined with a heated air plenum ventilation system. Elsewhere in the building heating is by 'Frenger' acoustic heated ceilings. All windows are double-glazed to reduce heat losses. Many of the rooms are provided with inlet and extract ventilation, particularly those fitted with dark blinds.

The main laboratory is planned on a repeating bay unit $7 \mathrm{ft} .6 \mathrm{in}$. wide and $16 \mathrm{ft}$. deep, with laboratory services arranged beneath the windows in a service rack. The services available in every bay of the building include alternating current supplies at $415 \mathrm{~V}$. (3-phass) and $240 \mathrm{~V}$. and $6 \mathrm{~V}$. (single phase) and direct current at $240 \mathrm{~V}$. and $24 \mathrm{~V}$. Hot and cold water, gas and compressed air are also available.

It was estimated that one and a half million gallons of cooling water per annum would be required for diffusion pumps, compressors, etc., and a recirculation system is therefore provided. This service is generally available in the centres of rooms, together with $240 \mathrm{~V}$. a.c. and one other service at ehoice.

Walls throughout the building are plastered and tinted and the doors are decorated in bright colours. The floors of most rooms are covered with 'Tarkett P.V.C.' tiles and the corridors with 'Korkoid'. The library has been designed to enable the beautiful surroundings of the Laboratory to be seen to advantage. Part of a gift from Imperial Chemical Industries, Ltd., has been used to provide books for the library, which will be especially useful during the next three years when the University Library is still on the old University site. Office accommodation for a theoretical physics group is provided near the library. This group is working on the application of quantum mechanics and statistical mechanies to problems in solid state physics, in particular crystal lattice vibrations, lattice imperfections and magneto-optic effects in semiconductors.

Most of the experimental work in the Laboratory is concerned with the physies of the solid state. One research group is studying the effects of imperfections in erystal structure on physical properties, particularly with reference to radiation damage (defects produced by irradiation with pile neutrons and other hign-energy particles). A 2-MeV. Van de Graaff generator (purchased with a grant from the Department of Scientific and Industrial Research) is used to produce defects in a controlled way. It is housed in a small building at a convenient distance from the main laboratory.

A section of the research space is assigned to the radio-tracer laboratory, which is mainly concerned with atomic diffusion in metals. This laboratory contains also a mass spectrometer which is used to assist biological as well as physical research.

A research group, supported by the Admiralty, is working on the surface properties of semiconductors. Methods of breaking germanium in a very high vacuum $\left(10^{-9}-10^{-10} \mathrm{~mm}\right.$. mercury) so as to expose a crystal plane have been devised, and the gradual contamination of these surfaces is being studied. Work on the etching of surfaces is being studied using high-quality optical microscopes, and an $E . M .6$ electron microscope is on order. Associated Electrical Industries, Ltd., have kindly agreed to provide a technical assistant to work this instrument for three years. Studies of solids by X-ray and electron diffraction are also in progxess. The Royal Society has given a grant to assist the development of highvoltage electron diffraction using the Van de Graaff generator.

The Laboratory is equipped for spectroseopic studies for the infra-red, visible, ultra-violet and soft X-ray regions. The apparatus is used for measurements on solids chiefly in the infra-red and visible regions and in the vacuum ultra-violet. The results on gases have applications to studies on the upper atmosphere and to the physics of hot plasmas.

A biophysical investigation on vision is supported by the U.S. Public Health Service.

When the Laboratory was designed, the number of students in the University of Reading was expected to become stable at a figure in the range $1,500-2,000$. An increase to 3,000 is now contemplated. The Laboratory will have to provide for larger numbers in the Physics Department and also for the early development of at least two new departments in the physical sciences. The design of the building provided for possible extension which, it was thought, might be needed after twenty-five years. The naw conditions have led to discussion of this extension even before the building was opened.

\section{R. W. Ditchburn}

\title{
GOVERNING TECHNICAL COLLEGES
}

HANDBOOK, "The Technical Colleges and their
Government", issued by the Joint Federation of
British Industries Technical Colleges Committee
under the auspices of the Federation's Edueation
Committee, provides a concise but keen industrial appraisal of the structure of technical education, its historical background, academic pattern and finance as well as a close discussion of the government of technical colleges (pp. vii +44 . F.B.I. Handbook. London : Federation of British Industries, 1960. 5s.). 
Appendixes included a policy statement on the finance of advanced sandwich courses issued by the Federation, the Ministry of Education's Circular 7/59 on Governing Bodies for Major Establishments, and $a$ selected bibliography which is thoroughly representative.

The recommendations based on this survey emphasize that it is the function of governors to ensure that their college fulfils its role as an academic institution within the national and regional framework of further education. To do so involves strong links with industry, commerce and the professions; a constant awareness of the changing needs of their students; and adequate powers to implement the governing body's decisions. Governors nominated by special interests can and should bring their special experience or background to bear on the affairs of the college, but the handbook emphasizes that the governors serve to promote the interests of the college and that they should be aware that each college occupies a distinct place in the pattern of further education as a whole.

On size, the handbook suggests a membership of about twenty as ideal, and it should include members of the professions with which the college is mainly concerned and of the universities. The contribution which headmasters of secondary schools could make should be considered and provision for co-opting independent persons with special knowledge or experience, representative of ex-students and for continuity is recommended. Stress is laid on the importance of the full implications of the recom. mendations of the Ministry of Education in regard to the powers of the governing body, and the handbook stresses the importance both of the power of governors being commensurate with the responsibilities they are asked to assume and of adjusting procedure to ensure the best possible use of the governors' time.

One meeting of two to three hours a term is suggested as covering most requirements, but apart from attendance at formal meetings of the governing body and its committees, governors can and should play a valuable part in the life of the college, and it is recommended that they should be encouraged to do so. Departmental advisory committees are usually appointed for each major discipline studied at a college, and these should consist of experts from industry or commerce, members of the governing body and the teaching staff and representatives of the appropriate professional body. They may also include H.M. Inspectors and should have room for co-opted independent experts. Close links beiween the advisory committees and the governing body are essential, but the constitutional position of advisory committees will vary according to the subject, and in fiolds which are undergoing continuous change, the establish. ment of permanent advisory committees may be advisable.

\section{SOUTH-EASTERN UNION OF SCIENTIFIC SOCIETIES}

\begin{abstract}
$\mathrm{T}$ HE South-Eastern Union of Scientific Societies held its sixty-fifth annual congross in Ipswich, during April 22-25, under the presidency of the Earl of Cranbrook. The headquarters of the congress was at Ipswich School, where an exhibition of natural history was on display. A young naturalists' evening was arranged and questions from the audience were answered by a panel under the chairmanship of Maxwell Knight. Lord Cranbrook's presidential address to the Union was on "East Anglian Mammals", and he began by explaining that most of the area is highly cultivated, therefore the habitats are largely man-made. The red deer in East Anglia are possibly the progeny of escapes of those introduced from Scotland and are larger than those of ths same species in Scotland, the increased size being due to an environmental change. Introduced roe deer are now flourishing in the Breckland.

Dealing with the seal population he said that both common and grey species occurred, a colony of grey seals being established during 1958 on Grove Sands, off Yarmouth, which are dry at the high-water mark. Ringing experiments are being made for recording movements of individuals, breeding places and the months on which the young of different species are born.
\end{abstract}

Lord Cranbrook said that for some obscure reason there appeared to be a natural barrier on the EssexSuffolk border which prevented a number of mammals from crossing to suitable habitats in Norfolk and Suffolk. The distribution of the dormouse, horse-shoe bat and grey squirrel is limited to the south of the
Stour valley although the red squirrel is abundant in the coniferous woods of the Breckland. Coypu numbers increase and the animal has become a nuisance, damaging farm erops and banks of ditches and streams. Scientific investigation is necessary to find the steps to be taken for control. Defending the policy of the Forestry Commissioners in planting mainly conifers, he said that pine forests are useful for the preservation of mammals, badgers are increasing in numbers, and the pine marten, which is increasing its range, may be expected to reach the area in the near future. The question of the black rat race in the Fens needs careful consideration; there appears to be two varieties common in the south and east of England and their control may be necessary. He concluded his address by comparing the growth of teeth of the field and water voles. In the former the teeth continue to grow throughout their life, as much as $2 \frac{1}{2}$ in. a year, a corresponding amount being worn away by the hard food they consume. In the case of the water vole the teeth cease to grow when the animal is adult, calification then aiding tho resistance to wear.

The presidential address to the Archacological Section was given by Mr. N. Smedley on "Archæology in Suffolk". Speaking on the early investigators he mentioned the finding of an Acheulean implement by John Frere in 1797 and the scepticism with which the suggestion of man's existence before the present world conditions was received. He tracod the developrnent of the beaker pottery forms through the neolithic, bronze and iron ages. Roman times in Suffolk 